\title{
Trap-effectiveness and response to tiletamine- zolazepam and medetomidine anaesthesia in Eurasian wild boar captured with cage and corral traps
}

\author{
José Angel Barasona ${ }^{*}$, Jorge Ramón López-Olvera², Beatriz Beltrán-Beck, Christian Gortázar and Joaquín Vicente ${ }^{1}$
}

\begin{abstract}
Background: Capture, handling and chemical restraint are basic techniques often needed for research or management purposes. The aim of this study was testing a combination of tiletamine-zolazepam (TZ) (3 mg/kg) and medetomidine (M) $(0.05 \mathrm{mg} / \mathrm{kg})$ on Eurasian wild boar (Sus scrofa). A total of 77 free-ranging wild boar were captured by means of portable cages and corral traps and then anaesthetized with intramuscular darts using a blowpipe. The individual response to chemical immobilization was characterized using anaesthetic, clinical, and serum biochemical variables. After the procedure, 14 of these wild boar were monitored for 20 days using GPS-GSM collars.
\end{abstract}

Results: Pre-release mortality during capture and handling (6.5\%) was associated with severe trauma in corral traps. Capture specificity for wild boar was $96.3 \%$ and trapping effort was 16.5 days per captured wild boar. Mean induction period was $4.5 \pm 2.2 \mathrm{~min}$, hypnosis period enabling effective handling was $61.6 \pm 25.4 \mathrm{~min}$, and recovery period was $12.8 \pm 12.1 \mathrm{~min}$. No heart or respiratory failure due to added stress occurred and post-release monitoring by GPS-devices revealed no mortality due to anaesthesia. According to the best statistical model obtained, the main factor driving anaesthetic efficacy and stress indicators is trap type.

Conclusions: Both cage and corral traps are efficient methods to capture wild boar. Cage traps are safer, as demonstrated by mortality rates as well as anaesthetic, physiological, and serum biochemical responses. This anaesthetic protocol is useful for prolonged handling of wild boar and allows sampling and collecting data for ecological and epidemiological studies.

Keywords: Anaesthesia, Capture, Medetomidine, Stress, Tiletamine, Zolazepam, Wild boar

\section{Background}

Social sensitivity regarding environmental issues, animal health and animal welfare has increased worldwide $[1,2]$. These issues must be addressed when implementing research and management of wild ungulates $[3,4]$, which usually include trapping free ranging animals. The Eurasian wild boar (Sus scrofa, L. 1758) is one of the terrestrial mammals with the broadest geographic range $[5,6]$, and has an ecological, health and economic impact

\footnotetext{
* Correspondence: joseangel.barasona@uclm.es

'Sanidad y Biotecnología (SaBio), Instituto de Investigación en Recursos Cinegéticos (IREC; CSIC - UCLM - JCCM), Ronda de Toledo, Ciudad Real s.n. 13005, Spain

Full list of author information is available at the end of the article
}

[7-9]. Several capture and handling studies, mostly using baited box traps and corral traps, have been carried out on this species [10-12]. Capture and either physical or chemical immobilization of wild boar convey risks of mortality, but chemical immobilization is usually required for handling [13-17]. Different factors, such as capture method, previous human-induced stress and environmental conditions may affect the efficacy of chemical restraint $[18,19]$ and induce severe stress $[14,17,19]$.

The most commonly drugs used in chemical immobilization of wild pig species are cyclohexamines (ketamine and tiletamine) and $\alpha_{2}$-adrenergic agonists (xylazine, $\mathrm{X}$; detomidine; romifidine; medetomidine, $\mathrm{M}$ )

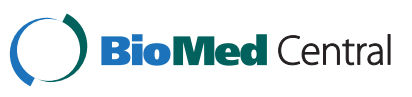


[15-17,20,21]. Cyclohexamines are anaesthetics that cause electroencephalographic dissociation of the activity of the central nervous system, inducing visceral analgesia combined with superficial anaesthesia, persisting palpebral, laryngeal and pedal reflexes [22,23]. The $\alpha_{2}$ adrenergic agonists provide sedation, visceral analgesia and muscle relaxation [24-26]. The combination of these two types of drugs allows using lower doses to achieve hypnosis, analgesia and muscle relaxation [27]. The combination of $\alpha_{2}$-adrenergic agonists ( $M$ or $\left.X\right)$ and an opioid (morphine derivates) decreases the dose of the main anaesthetic, either propofol, thiopental, tiletamine or alfaxalone. This also minimizes the adverse effects of drugs used alone, e.g. agitated and violent recoveries in collared peccaries (Tayassu tajacu) anesthetized only with ketamine $[13,28]$.

Several studies have assessed the usefulness of anaesthetic combinations to immobilize physically captured wild pig species [15-17,20,21]. The anaesthetic combination chosen in this study has been described for prolonged surgical procedures (high doses) by [20] ( $5 \mathrm{mg} / \mathrm{kg}$ of tiletamine-zolazepam, TZ and $0.1 \mathrm{mg} / \mathrm{kg}$ of $\mathrm{M}$ in 8 wild boar) and [29] (5 mg/kg of $\mathrm{TZ}$ and 0.025 $\mathrm{mg} / \mathrm{kg}$ of $\mathrm{M}$ in 9 farmed will boar). Although serum biochemistry is a valuable tool to assess the physiological status of wild animals and the effect of handling and treatments, there is scarce knowledge on serum biochemistry values in wild boar [30-33], and few studies have investigated the physiological effects of anaesthesia after physical capture in this species [34].

The aims of this study were (1) to evaluate the efficiency and safety of a combination of $\mathrm{TZ}$ and $\mathrm{M}$ in freeranging wild boar captured by means of cage and corral traps; and (2) to determine the factors affecting the anaesthetic and physiological individual response to chemical immobilization of wild boar physically captured with cage and corral-traps, using anaesthetic, clinical, and serum biochemical variables.

\section{Methods}

\section{Study area and period}

The study was conducted between February and November 2010 in Montes de Toledo $\left(39^{\circ} 25^{\prime}\right.$ to $39^{\circ} 16^{\prime} \mathrm{N}, 4^{\circ}$ $05^{\prime}$ to $\left.4^{\circ} 23^{\prime} \mathrm{W}\right)$, in the region of Castilla-La Mancha, South-central Spain. This is a 36,000 hectares area where altitude ranges between 590 to 1010 meters a.s.l. Climate is Mediterranean, with an average temperature of $14.1^{\circ} \mathrm{C}$. The habitat is characterized by evergreen oak (Quercus ilex) scrublands with scattered pastures and small crops, conforming dehesas (savannah-like habitats).

\section{Capture method}

Seven $3 \times 1.2$ meters portable cage traps [10] and seven corral traps each consisting of seven panels over 5 meters wide [11] were used to capture wild boar. The portable cage traps were triggered when a wild boar stepped on a mobile bottom platform in the centre of the trap, which closed simultaneously the two drop gates of the trap. The corral traps had a single drop door and a trigger mechanism of root sticks. Traps were baited with corn every 2-4 days both inside and outside the trap and monitored with camera traps (Model IR-3BU, Leaf River Outdoor, Taylorsville, Mississippi, USA) to determine the time of activation. Once activated, each trap was revised daily, early in the morning to avoid that the animals reached high temperatures within the traps (maximum temperature in daytime reached up to $36.9^{\circ} \mathrm{C}$ ). Study procedures were approved by the Animal Experiment Committee of Castilla-La Mancha University and were designed and developed by scientists (B and $\mathrm{C}$ animal experimentation categories) approved by the Spanish Ethic Committee.

\section{Anaesthesia and monitoring}

A combination of $\mathrm{TZ}$ (Zoletil $100 \mathrm{mg} / \mathrm{ml}$, Virbac, France, target dose $3 \mathrm{mg} / \mathrm{kg}$ ) and $\mathrm{M}$ (Medetor ${ }^{\odot}$, Virbac, France, target dose $0.05 \mathrm{mg} / \mathrm{kg}$ ) was injected intramuscularly in the femoral region with $5 \mathrm{ml}$ anaesthetic darts (Telinject ${ }^{\circ}$, Römerberg, Germany) using a $14 \mathrm{~mm}$ diameter blowpipe (Telinject ${ }^{\bullet}$, Römerberg, Germany), after visually estimating the weight of each animal in the trap. After sedation, wild boar were removed from the traps and blindfolded.

Heart rate and oxygen saturation were measured and registered every 5 minutes from hypnosis to recovery using a portable modified pulse oximeter (G1B Pulse Oximeter, Quirumed ${ }^{\circledR}$, Moncada, Spain). Respiratory rate was measured every 10 minutes by the same person by direct observation of chest wall movements. Rectal temperature was measured with a digital thermometer every 10 minutes. The following anaesthetic periods were registered: human presence until injection (HPI; from human arrival to the cage to injection time); induction period (IP; from injection to the loss of palpebral reflex and the possibility of handling); hypnosis period (HP; from loss of response to first movement and response to stimuli), and recovery period (RP; from first response to total coordination, walking without ataxia).

The wild boar captured were classified as juveniles $(<24$ months of age) or adults ( $>24$ months of age) based on the eruption of molars and premolars [35,36]. Weight was measured with a scale, and total length (from snout to tail base) and thoracic perimeter were measured with measure tape and registered.

Blood was obtained from the ophthalmic sinus at the medial angle of the eye behind the nictitating membrane [37]. Blood samples were immediately refrigerated and transported to laboratory, within two hours after 
collection, where serum and plasma were obtained for biochemistry and blood smears were prepared.

\section{Serum biochemistry}

Serum alanine aminotransferase (ALT), alkaline phosphatase (AP), aspartate aminotransferase (AST), creatine kinase $(\mathrm{CK})$, and lactate dehydrogenase (LDH) activities and serum lactate, glucose, cholesterol, triglycerides, urea, creatinine, sodium, and potassium concentrations were determined by means of an automated analyser (Olympus AU400, Olympus, Tokyo, Japan).

\section{Post-release monitoring}

Collars provided with a satellite position capture system (GPS) [38] and a global system for mobile communications (GSM) [39] were fitted to 14 wild boar over $40 \mathrm{~kg}$. The collars were set to record one position every hour, sending encoded packets with 20 positions to the central station when mobile phone coverage was sufficient. Activity patterns were calculated for each collared animal by estimating the average speed obtained from the distance between two consecutive GPS locations. Postcapture monitoring was performed for 20 days. Collarless wild boar were ear-tagged. In addition, all the wild boar were identified with a microchip (FDX-B transponders, Allflex ${ }^{\circ}$, France) placed caudal to the ear. The entire procedure lasted less than 20 minutes in all cases. The body surface of the wild boar was wetted with cold water prior to release in order to avoid hyperthermia when rectal temperature exceeded $40^{\circ} \mathrm{C}$.

\section{Statistical analysis}

Descriptive statistics were calculated for physiological variables and anaesthetic periods (Statistica 7, Statsoft ${ }^{\circ}$, Tulsa, USA). In order to compare the number of wild boar captured per trap type and the GPS activity patterns (average speed) during the day post-release (10 hours after) against the 3 successive monitoring days, Mann-Whitney's U test was used. Identity link generalized linear models (GLMz) [40] were carried out to explain the dependent variables: anaesthetic periods (IP, HP and RP), physiological (body temperature, respiratory and heart rates), and biochemical (ALT, ALP, CK, AST, LDH, lactate, glucose, cholesterol, sodium, potassium, urea, creatinine, triglycerides and total proteins) values (SPSS Statistics 18 for Windows, IBM ${ }^{\circ}$, Armonk, USA). In case wild boar were recaptured only the first measure was used to build the GLMz. Also individuals presenting trauma or obvious cachexia likely due to generalized tuberculosis were not included in the models. Wild boar injected with $\alpha_{2}$-antagonist atipamezole (Antisedant ${ }^{\circ} 5 \mathrm{mg} / \mathrm{ml}$, Orion Pharma, Finland, target dose $0.20 \mathrm{mg} / \mathrm{kg}$ ) were excluded from the statistics. Serum enzymatic activities, which showed exponential variations, as we all the length of IP, HP, and RP were logarithmically transformed, in order to avoid overdispersion. The categorical independent variables were sex $(1=$ male, 2 = female $)$, age class $(1=$ juvenile, $2=$ adult $)$ and type of trap ( $1=$ cage trap, $2=$ corral trap). Independent variables included as covariates were anaesthetic dose, body condition (as chest circumference to body length ratio) and maximum environmental temperature recorded the day of capture.

\section{Results}

A total of 80 animals were captured: 77 wild boar, two adult badgers (Meles meles) and one yearling red deer (Cervus elaphus). Therefore, capture specificity for wild boar was $96.3 \%$. The first capture took place on average $28.2 \pm 8$ days (range $=15-45$ ) after starting baiting the trap. Each capture required on average $9 \pm 3.6$ visits to the trap (range=4-16). Considering the baiting and trapping periods altogether, the average trapping effort was $16.5 \pm 12.7$ days per captured wild boar (Table 1).

Pre-release mortality during capture and handling was $6.5 \%(\mathrm{n}=5)$; four deaths were associated with severe trauma (and subsequent euthanasia) in corral traps and one was due to hyperthermia (haemorrhages and cervical-thoracic congestion at necropsy) in a cage trap. The number of wild boar captured per trapping event was significantly higher for corral traps $(4.73 \pm 3.46)$ than for cage traps $(1.92 \pm 1.38)$ (Mann-Whitney $U$ test; $\mathrm{U}=-2.36, p=0.02$ ) (Table 1 ). Capture selectivity by trap, gender, and age is also detailed in Table 1.

Out of the 77 captured wild boar, 42 were anaesthetized and 35 (weighing less than $15 \mathrm{~kg}$ ) were handled without using chemical immobilization [41]. The mean dose used per anaesthetized wild boar was $2.9 \pm 0.39 \mathrm{mg} / \mathrm{kg}$ of $\mathrm{TZ}$ and $0.048 \pm 0.006 \mathrm{mg} / \mathrm{kg}$ of $\mathrm{M}$. This was an $11 \%$ deviation from the target dose, due to errors in weight estimation. Double injection was needed only in one very excited and aggressive wild boar captured in a corral trap. Therefore, anaesthetic efficiency (percentage of fully anesthetized wild boar with a single injection) was $97.6 \%$. For the 41 wild boar that received single injections, IP was $4.5 \pm 2.2 \mathrm{~min}$., HP enabling effective handling was $61.6 \pm 25.4 \mathrm{~min}$. and RP was $12.8 \pm$ $12.1 \mathrm{~min}$. The $\alpha_{2}$-antagonist atipamezole injected intramuscularly in 4 wild boar (40 min after anaesthetic drug injection) was effective in reversing immobilization, with recovery (total coordination) occurring $8.4 \pm 2.3 \mathrm{~min}$.

Figures 1 and 2 show average values and trends for respiratory rate and body temperature, and for heart rate and blood oxygen saturation, respectively. Respiratory rate, heart rate and rectal temperature decreased progressively, whereas oxygen saturation increased from the beginning of monitoring and remained stable between 90 and $96 \% \mathrm{SpO}_{2}$ thereafter. No signs of vagal 
Table 1 Capture data for the two physical capture methods (cage-traps and corral-traps) used in this study (adapted from López-Olvera et al. 2009)

\begin{tabular}{|c|c|c|c|c|c|c|c|c|c|c|c|c|c|c|c|c|}
\hline \multirow[t]{3}{*}{$\begin{array}{l}\text { Capture } \\
\text { method }\end{array}$} & \multirow[t]{3}{*}{$\begin{array}{l}\text { Number } \\
\text { of traps }\end{array}$} & \multirow{3}{*}{$\begin{array}{c}\text { Days } \\
\text { before } \\
\text { activation } \\
\text { (mean; } \\
\text { range) }\end{array}$} & \multirow{3}{*}{$\begin{array}{l}\text { Days } \\
\text { activated } \\
\text { (mean; } \\
\text { range) }\end{array}$} & \multirow[t]{3}{*}{$\begin{array}{l}\text { Days } \\
\text { of } \\
\text { work }\end{array}$} & \multirow[t]{3}{*}{$\begin{array}{l}\text { Person- } \\
\text { days of } \\
\text { work }\end{array}$} & \multirow{3}{*}{$\begin{array}{l}\text { Number } \\
\text { of } \\
\text { capture } \\
\text { events }\end{array}$} & \multirow{3}{*}{$\begin{array}{l}\text { Number } \\
\text { of } \\
\text { multiple } \\
\text { captures }\end{array}$} & \multirow[t]{3}{*}{$\begin{array}{l}\text { Wild } \\
\text { boar } \\
\text { captured }\end{array}$} & \multirow{3}{*}{$\begin{array}{c}\text { Wild } \\
\text { boar } \\
\text { per } \\
\text { capture } \\
\text { (mean; } \\
\text { range) }\end{array}$} & \multirow[t]{3}{*}{ Mortality } & \multirow{3}{*}{$\begin{array}{l}\text { Days } \\
\text { per wild } \\
\text { boar } \\
\text { (mean; } \\
\text { range) }\end{array}$} & \multirow{3}{*}{$\begin{array}{l}\text { Person- } \\
\text { days } \\
\text { per } \\
\text { wild } \\
\text { boar } \\
\text { (mean; } \\
\text { range) }\end{array}$} & \multicolumn{4}{|c|}{$\begin{array}{c}\text { Gender and age } \\
\text { class ( } Y=\text { yearling; } \\
A=\text { adult })\end{array}$} \\
\hline & & & & & & & & & & & & & \multicolumn{2}{|c|}{ Male } & \multicolumn{2}{|c|}{ Female } \\
\hline & & & & & & & & & & & & & $Y$ & A & $Y$ & A \\
\hline Cage-trap & 7 & $26 ; 11-44$ & $1.8 ; 1-5$ & 103 & 135 & 13 & 5 & 25 & $1.9 ; 1-5$ & 1 & $21.8 ; 2-46$ & $7.9 ; 1-16$ & 7 & 8 & 6 & 4 \\
\hline Corral-trap & 7 & $28.9 ; 15-45$ & $2.1 ; 1-3$ & 114 & 154 & 11 & 9 & 52 & 4.7; 1-11 & 4 & $10.2 ; 4-33$ & $4.8 ; 2-16$ & 22 & 8 & 18 & 4 \\
\hline TOTAL & 14 & $27.4 ; 11-45$ & $2 ; 1-5$ & 217 & 289 & 24 & 14 & 77 & $3.2 ; 1-11$ & 5 & $16.5 ; 2-46$ & $6.5 ; 1-16$ & 29 & 16 & 24 & 8 \\
\hline
\end{tabular}




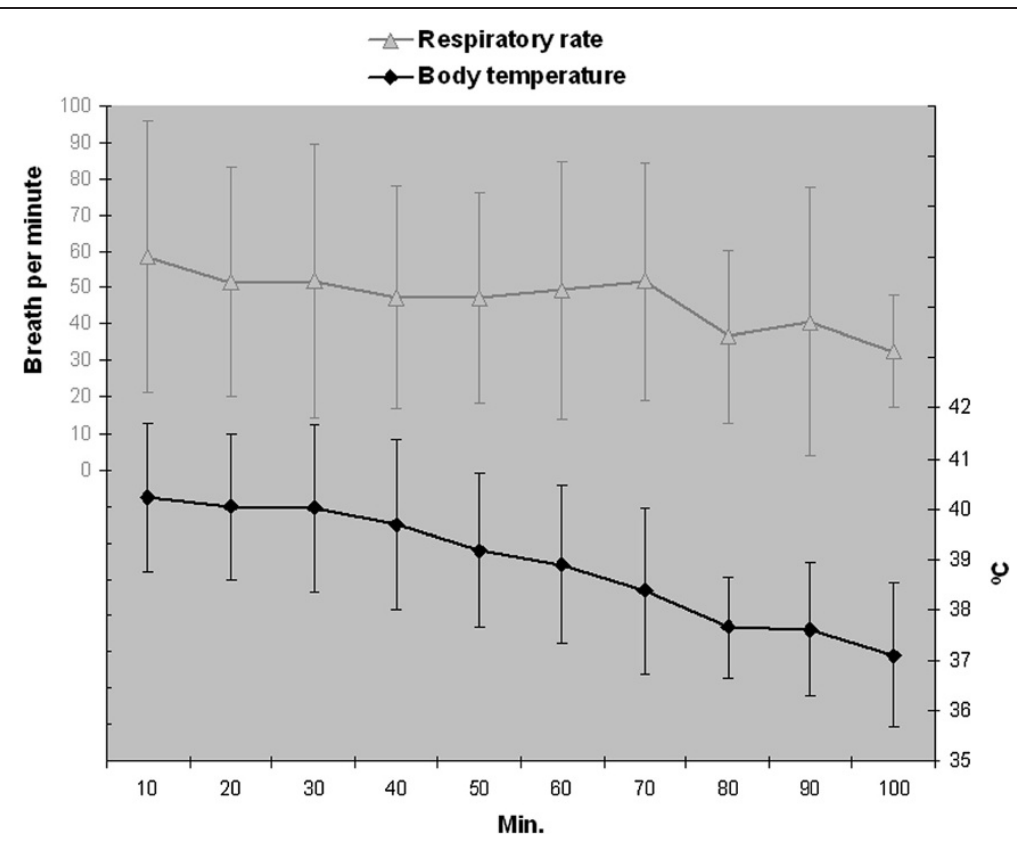

Figure 1 Mean \pm SD respiratory rate and body temperature every $10 \mathrm{~min}$.

cardiorespiratory depression after drug administration were detected, but one wild boar presented transient atrio-ventricular arrhythmia during the deep anaesthetic phase. Body temperatures above $40^{\circ} \mathrm{C}$ were exceeded by 18 (47\%) wild boar, of which 55\% were males and $72 \%$ juveniles, mainly at the beginning of the anaesthesia.

After discarding recaptured wild boar $(\mathrm{n}=1)$ and those presenting trauma $(n=5)$ or severe generalized tuberculosis $(n=2)$, the remaining 35 wild boar were included in the models. Table 2 shows the results of the GLMz and the value for each categorical variable to explain anaesthetic periods and biochemical variables. Tables 3 and 4 show the values for these variables.

Heart rate after 40 minutes and initial rectal temperature were significantly higher in the wild boar captured in corral traps, as well as serum lactate, glucose, potassium, and triglyceride concentrations, whereas HP was significantly higher in wild boar captured in cage traps. Serum AST activity was significantly higher in females than in males. Young wild boar had significantly shorter RP and higher serum ALP activity than adults. IP was significantly longer in the corral-trap captured and adult

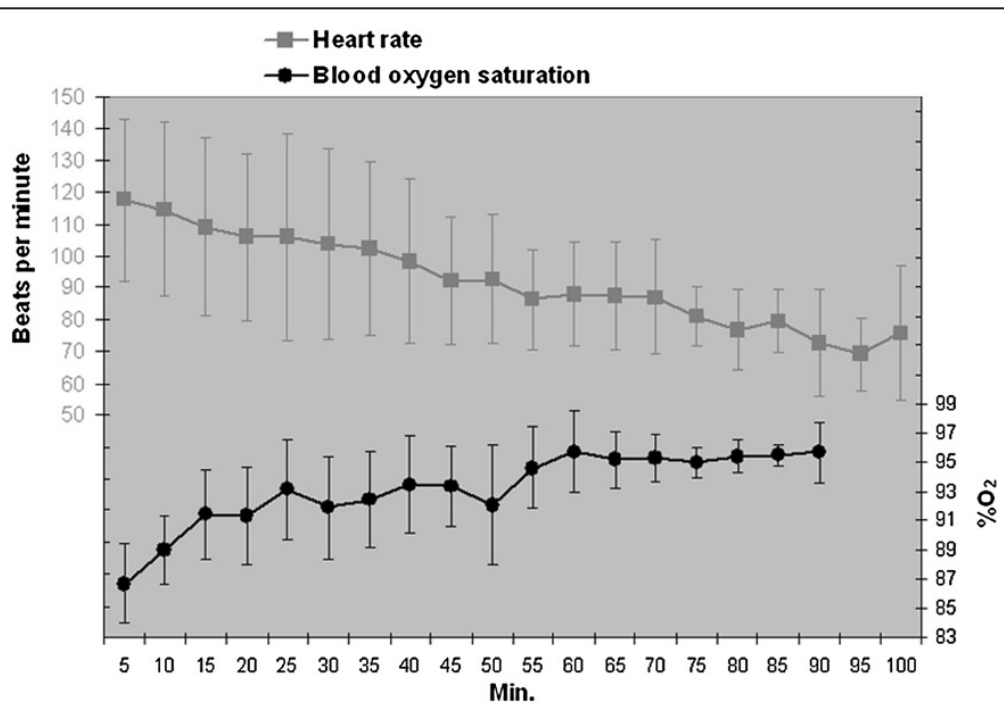

Figure 2 Mean \pm SD oxygen saturation and heart rate every $5 \mathrm{~min}$. 
Table 2 Results of Generalized Linear Models to identify factors associated variations in the anaesthetic periods, of the association between parameter estimator ( $\beta$ ) for GLMz where in categorical variables "gender" "age class" and "type trap" the reference value of the parameter estimator was 0 for gender "female", age class "yearling" and type trap "cage trap"

\begin{tabular}{|c|c|c|c|c|c|c|c|}
\hline \multirow[t]{2}{*}{ Dependent variables } & \multicolumn{7}{|c|}{ Independent variables } \\
\hline & Trap type & Gender & Age class & Dosage & Body condition & $\begin{array}{l}\text { Environmental } \\
\text { temperature }\end{array}$ & $\begin{array}{l}\text { Deviance } \\
\text { difference }\end{array}$ \\
\hline Log induction period & $-0.41^{* * *}$ & & $-0.28^{* *}$ & & $-1.61 * *$ & $0.01 *$ & 0.65 \\
\hline Log hypnosis period & $0.30 *$ & & & & & & 0.31 \\
\hline Log recovery period & & & $-0.6^{* * *}$ & $0.49 * *$ & & & 0.62 \\
\hline Initial respiratory rate & & & & $0.21 *$ & $-1.81 * *$ & & 0.24 \\
\hline $40 \mathrm{~min}$ respiratory rate & & & & & & & 0.59 \\
\hline Initial heart rate & & & & & & & 0.26 \\
\hline 40 min heart rate & $-0.08^{*}$ & & & & $-0.48^{*}$ & & 0.36 \\
\hline Initial body temperature & $-1.17^{*}$ & & & & & $0.10^{* *}$ & 0.78 \\
\hline 40 min body temperature & & & & & & & 0.74 \\
\hline Log ALT & & & & $-0.27^{* *}$ & & & 0.57 \\
\hline Log ALP & & & $0.24^{*}$ & $-0.44^{* * *}$ & & & 0.63 \\
\hline $\log C K$ & & & & $-1.17^{* * *}$ & $3.85^{*}$ & & 0.62 \\
\hline Log AST & & $-0.29 *$ & & $-0.62^{* * *}$ & & & 0.62 \\
\hline Log LDH & & & & $-0.62^{* * *}$ & $2.259^{*}$ & & 0.59 \\
\hline Lactate & $-0.13^{*}$ & & & $-0.18^{* *}$ & & & 0.24 \\
\hline Glucose & $-0.27^{* * *}$ & & & & $-1.18^{* *}$ & & 0.72 \\
\hline Cholesterol & & & & & & $-0.05^{* *}$ & 0.64 \\
\hline Sodium & & & & & & $0.002^{*}$ & 0.29 \\
\hline Potassium & $-4.53^{*}$ & & & & & $-0.40^{* *}$ & 0.59 \\
\hline Log urea & & & & $-0.19^{*}$ & & $0.01 *$ & 0.28 \\
\hline Creatinine & & $-0.6^{*}$ & $-0.16 * * *$ & & & $0.01 *$ & 0.64 \\
\hline Triglycerides & $-0.34^{* * *}$ & & & $-0.34^{* *}$ & & & 0.54 \\
\hline Total protein & & $-0.35^{*}$ & $-0.04^{* *}$ & & & & 0.45 \\
\hline
\end{tabular}

Body condition was measured as chest circumference to body length ratio. The proportion of explained deviance (Deviance difference) in each model is shown. $P$ values are shown: ${ }^{*} \mathrm{p}<0.05,{ }^{* *} \mathrm{p}<0.01,{ }^{* *} \mathrm{p}<0.001$.

wild boar than in the cage-trap captured and young ones, respectively. Serum creatinine and total protein concentrations were significantly lower in the female and young wild boar as compared to males and adults (Tables 2, 3 and 4). Higher dosages increased RP and initial respiratory rate, and were negatively correlated with serum enzymatic activity (ALT, ALP, CK, AST, and LDH) and serum lactate, urea and triglycerides concentration. The wild boar with better body condition experienced a shorter IP, and had lower initial respiratory rate, heart rate at 40 minutes, and serum glucose concentration, but showed higher serum CK and LDH activities than the wild boar in lower body condition. Finally, higher environmental temperatures increased IP and initial body temperature, as well as serum sodium, urea, and creatinine concentrations, and decreased serum cholesterol and potassium concentrations (Table 2).
The post-capture activity monitoring of 14 GPS collared wild boar evidenced no mortality for the first 20 days. In fact, no reduction of activity patterns recorded in terms of average speed was observed in the first 10 hours post-capture $(262 \pm 115 \mathrm{~m} / \mathrm{h})$ compared with the same period in the consecutive 3 days $(265 \pm 144 \mathrm{~m} / \mathrm{h})$, according to Mann-Whitney $\mathrm{U}$ test $(\mathrm{U}=27.5, p>0.05)$.

\section{Discussion}

Capture method

Both capture methods, the cage-trap and the corral-trap, were effective and provided good average yield. The higher yield in corral-traps than in cage-traps agrees with previous reports [17]. Nevertheless, the average yield for cage-traps was also higher than one wild boar per capture. There was a high variability among locations, probably due to marked differences in local wild 
Table 3 Mean values and reference ranges for the anaesthetic, physiological, and serum biochemical variables analyzed in 35 physically captured and anaesthetized wild boar (Sus scrofa)

\begin{tabular}{|c|c|c|c|c|c|}
\hline & $\mathbf{N}$ & Mean & SD & Range & Reference ranges \\
\hline Induction period (min) & 35 & 4.81 & 2.92 & 13.16 & N.A. \\
\hline Hypnosis period (min) & 32 & 61.67 & 25.36 & 106.12 & N.A. \\
\hline Recovery period (min) & 30 & 14.25 & 13.41 & 46.5 & N.A. \\
\hline Initial respiratory rate $(/ \mathrm{min})$ & 35 & 61.74 & 40.52 & 132 & $32-58^{*}$ \\
\hline $40 \mathrm{~min}$ respiratory rate $(/ \mathrm{min})$ & 32 & 48.47 & 31.96 & 146 & $32-58^{*}$ \\
\hline Initial heart rate (/min) & 35 & 114.94 & 27.75 & 116 & $70-120^{*}$ \\
\hline $40 \mathrm{~min}$ heart rate $(/ \mathrm{min})$ & 31 & 99.26 & 26.26 & 118 & $70-120^{*}$ \\
\hline Initial body temperature $\left({ }^{\circ} \mathrm{C}\right)$ & 35 & 40.27 & 1.52 & 5.5 & $38.70-39.80^{*}$ \\
\hline 40 min body temperature $\left({ }^{\circ} \mathrm{C}\right)$ & 31 & 39.77 & 1.77 & 5.9 & $38.70-39.80^{*}$ \\
\hline ALT (UI/L) & 35 & 64.91 & 28.18 & 129 & $38-153.70$ \\
\hline ALP (UI/L) & 35 & 111.15 & 57.70 & 244.5 & $45.60-122.50$ \\
\hline CK (UI/L) & 35 & 11,675 & 36,788 & 216,811 & $918-3,106$ \\
\hline AST (UI/L) & 35 & 260.09 & 442.42 & 2180 & $52.30-113.40$ \\
\hline LDH (UI/L) & 35 & 2805.78 & 1159.14 & 4752.3 & $791-976$ \\
\hline Lactate (mmol/L) & 35 & 13.44 & 5.28 & 27.1 & 22.05 \\
\hline Glucose (mmol/L) & 35 & 8.64 & 4.31 & 18.35 & $5.26-10.70$ \\
\hline Cholesterol (mmol/L) & 35 & 2.78 & 0.67 & 2.53 & $2.08-3.95$ \\
\hline Sodium (mmol/L) & 35 & 148.14 & 10.90 & 44.8 & $145.80-162.80$ \\
\hline Potassium (mmol/L) & 35 & 11.93 & 5.27 & 23.61 & $5.50-15.20$ \\
\hline Urea (mmol/L) & 35 & 4.95 & 1.46 & 6.79 & $2.40-5.25$ \\
\hline Creatinine $(\mu \mathrm{mol} / \mathrm{L})$ & 35 & 128.68 & 41.21 & 140.55 & $118.46-216.50$ \\
\hline Triglycerides (mmol/L) & 35 & 0.41 & 0.56 & 3.31 & $0.98-1.44$ \\
\hline Total protein $(\mathrm{g} / \mathrm{L})$ & 35 & 78.50 & 11.05 & 47.5 & $68.10-82.10$ \\
\hline
\end{tabular}

Wild boar reference values are provided by mean ranges from [33,42-44]. *Pig reference values adapted from [45].

boar abundance, which has been reported to influence capture yield [17].

Mortality fell within the previously reported $1.6 \%$ $10.6 \%$ range for this species [14,17], and was mostly caused by trauma in corral-traps (4 out of 5 mortality cases recorded). Trauma is a documented cause of mortality when capturing wild boar with corral traps $[17,19]$. Therefore, cage traps are considered to be safer than corral traps. Hyperthermia is a well-known cause of stress-related mortality in wild ungulates and particularly in wild boar, which are especially prone to hyperthermia when exposed to high environmental temperatures $[7,15,46]$. Moreover, an increase of activity before immobilization can lead to the production of heat in the muscle and severe elevation of body temperature [47].

Although only operator-activated methods are considered truly selective $[48,49]$, species-specificity for the capture methods used in this study was high (96.3\%), likely due to the use of camera traps, which allowed activating the traps once they were regularly visited by wild boar. Blind activation of the traps would produce earlier captures of wild boar, increasing efficiency, but would decrease specificity in turn. Concerning the age-selectivity of the study method, a greater proportion of young wild boar was captured in corral traps, due to the higher rate of capture of family groups (adult female with progeny), as previously reported [11,19].

\section{Anaesthesia}

The anaesthetic protocol used $(2.9 \mathrm{mg} / \mathrm{kg}$ of $\mathrm{TZ}$ and $0.05 \mathrm{mg} / \mathrm{kg}$ of $\mathrm{M}$ ) had a high anaesthetic efficiency (97.6\%), higher than the previously reported 55\% - 78\% range obtained with other anaesthetic protocols used in wild boar [14,15,17,41]. Moreover, it allowed the use of low volumes of drug, which has economic and practical interest as makes the protocol suitable for teleanaesthesia [50].

Anaesthetic induction was quick (4.5 minutes), shorter than the previously reported 5-10 minutes for a combination of $5 \mathrm{mg} / \mathrm{kg}$ of TZ and $0.025 \mathrm{mg} / \mathrm{kg}$ of M [29] or the 5 minutes reported for a combination of $3.2 \mathrm{mg} / \mathrm{kg}$ of $\mathrm{TZ}$ and $1.6 \mathrm{mg} / \mathrm{kg}$ of X [41], both in feral hogs, but slightly longer than the 3.3 minutes reported in wild boar with a higher dose (used for prolonged surgical 
Table 4 Value means (observed values / GLMz predicted values) for the anaesthetic, physiological, and serum biochemical variables showing statistically significant differences according to the independent categorical variables trap type, age class, and gender

\begin{tabular}{|c|c|c|c|c|}
\hline TRAP TYPE & \multicolumn{2}{|c|}{ Cage-trap } & \multicolumn{2}{|c|}{ Corral-trap } \\
\hline Hypnosis period (min) & \multicolumn{2}{|c|}{$74.79 / 72.63$} & \multicolumn{2}{|c|}{$49.60 / 45.46$} \\
\hline $40 \mathrm{~min}$ heart rate (/min) & \multicolumn{2}{|c|}{$\mathbf{8 4 . 8 9} / 92.86$} & \multicolumn{2}{|c|}{$96.71 / 103.54$} \\
\hline Initial body temperature $\left({ }^{\circ} \mathrm{C}\right)$ & \multicolumn{2}{|c|}{39.96 / 39.96} & \multicolumn{2}{|c|}{$40.54 / 40.42$} \\
\hline Lactate (mmol/L) & \multicolumn{2}{|c|}{$11.60 / 11.59$} & \multicolumn{2}{|c|}{$15.15 / 15.24$} \\
\hline Glucose (mmol/L) & \multicolumn{2}{|c|}{$6.63 / 6.63$} & \multicolumn{2}{|c|}{$9.92 / 9.94$} \\
\hline Potassium (mmol/L) & \multicolumn{2}{|c|}{$9.22 / 9.22$} & \multicolumn{2}{|c|}{$13.37 / 13.63$} \\
\hline Triglycerides (mmol/L) & \multicolumn{2}{|c|}{$\mathbf{0 . 2 1} / 0.21$} & \multicolumn{2}{|c|}{$0.59 / 0.62$} \\
\hline AGE CLASS & \multicolumn{2}{|c|}{ Young } & \multicolumn{2}{|c|}{ Adult } \\
\hline Recovery period (min) & \multicolumn{2}{|c|}{$10.28 / 7.38$} & \multicolumn{2}{|c|}{$\mathbf{2 2 . 1 8} / 23.11$} \\
\hline ALP (UI/L) & \multicolumn{2}{|c|}{$134.91 / 126.04$} & \multicolumn{2}{|c|}{$74.68 / 64.76$} \\
\hline GENDER & \multicolumn{2}{|c|}{ Female } & \multicolumn{2}{|c|}{ Male } \\
\hline AST (UI/L) & \multicolumn{2}{|c|}{$\mathbf{2 5 1 . 8 3 / 1 5 3 . 6 6}$} & \multicolumn{2}{|c|}{279.44 / 186.33} \\
\hline TRAP TYPE & \multicolumn{2}{|c|}{ Cage-trap } & \multicolumn{2}{|c|}{ Corral-trap } \\
\hline AGE CLASS & Young & Adult & Young & Adult \\
\hline Induction period (min) & $3.33 / 2.82$ & $4.11 / 4.51$ & $4.29 / 4.74$ & $9.87 / 7.36$ \\
\hline GENDER & \multicolumn{2}{|c|}{ Female } & \multicolumn{2}{|c|}{ Male } \\
\hline AGE CLASS & Young & Adult & Young & Adult \\
\hline Creatinine $(\mu \mathrm{mol} / \mathrm{L})$ & $97.38 / 98.88$ & $152.64 / 146.68$ & $122.29 / 120.30$ & $165.11 / 167.10$ \\
\hline Total protein (g/L) & $70.85 / 70.95$ & $79.20 / 78.70$ & $79.48 / 79.31$ & $87 n 23 / 87.40$ \\
\hline
\end{tabular}

procedures) of $5 \mathrm{mg} / \mathrm{kg}$ of $\mathrm{TZ}$ and $0.1 \mathrm{mg} / \mathrm{kg}$ of $\mathrm{M}$ [20]. The period of hypnosis allows the safe handling of animals, an appropriate duration of this period is required and varies depending on the specific procedures to perform. The mean HP (61.6 min) was longer than the period of 52 minutes obtained using TZ and X [41], or the 37.6 minutes reported for $\mathrm{TZ}$ alone [14]. Anaesthetic recovery is critical in wild boar $[13,14,28,51]$. For instance, it may be extended by residual activity when using ketamine $[13,28]$ or $\mathrm{TZ}[14]$ alone. The addition of $\mathrm{M}$, an $\alpha_{2}$-adrenergic agonist (alternatively $\mathrm{X}$ or romifidine may be used) reduced the required TZ dose, providing an anaesthetic RP much shorter (12.8 minutes), than the 43 minutes reported for the aforementioned combination of $3.2 \mathrm{mg} / \mathrm{kg}$ of TZ and $1.6 \mathrm{mg} / \mathrm{kg}$ of $\mathrm{X}$ in feral pigs [41]. In addition, atipamezole (an $\alpha_{2}$ adrenergic antagonist) was effective reversing the anaesthetic effects of $M$ [52]. Reversal of $M$ anaesthesia by atipamezole might uncover residual cyclohexamine effects if the antagonist is administered too early or at tiletamine high dose [53]. However, no such side effects were observed in this study. Further studies are needed to properly assess the efficacy and safety of anaesthetic reversal in anaesthetized wild boar.

The decreasing trends observed in heart rate, respiratory rate, and body temperature have been previously reported in domestic pigs using $\mathrm{TZ}$ combined with
$M$ [54] or X [54-56]. The oxygen saturation values registered coincide with those previously reported in anaesthetized wild boar, feral pigs, and peccaries and are comparable to the $93.2 \% \mathrm{SpO}_{2}$ considered indicator of good physiological condition during anaesthesia in these pig species $[41,57,58]$. Therefore, the anaesthetic protocol used seemed to be efficient and low risk.

Regarding activity patterns, no signs of movement restriction due to anaesthesia were evidenced during postrelease monitoring. However, the risk of secondary narcosis in the first hours after handling could not be evaluated in practice due to the low activity of wild boar during daytime [59] and the time rate of fixing positions (1 hour).

\section{Factors affecting anaesthesia}

Anaesthetizing free-ranging wild animals is always a risk, since no preanaesthetic evaluation can be properly performed (even estimating the weight is challenging), and several factors, either external (like trap type, environmental temperature, preanaesthetic stress, dose) or internal (gender, age, body condition) modulate individual response [60]. All these factors were significant in the present study.

According to the best statistical model obtained, the main factor affecting anaesthetic efficacy and stress indicators is trap type. The higher IP, heart rate at $40 \mathrm{mi}-$ nutes, initial rectal temperature, and serum lactate, 
glucose, potassium, and triglyceride concentrations and the shorter HP shown by the wild boar captured with corral traps indicate that they are more stressful for the wild boar during the preanaesthetic period than cagetraps, decreasing anaesthetic efficiency and animal welfare. That agrees with the higher mortality due to trauma experienced in this type of trap, and was probably related to the physical exercise before capture, since both lactate and potassium increases through anaerobic metabolism due to physical exercise $[61,62]$ and are indicators of capture myopathy [46]. Larger traps have already been reported to cause a higher stress and injuries in captured feral pigs [19]. Preanaesthetic stress is inversely related to the anaesthetic efficacy, requiring higher doses to achieve the same anaesthetic effect and causing dosage inefficacy $[17,18,41]$. We can not discard that the early darting of animal with blow pipe (HPI) before handling could influence itself animal reaction, but this was probably mediated by its association with the capture system, since it took more time, in average, darting animals in corral traps.

Age-related differences between young ( $<25$ months) and adult ( $>25$ months) wild boar in anaesthetic periods (IP and RP) and physiological variables (serum creatinine and total protein concentrations and ALP activity) are probably related to metabolic differences, since anaesthetic metabolism has been reported to be faster in young animals [63], therefore decreasing IP and RP. Regarding serum biochemistry, adults have higher serum protein concentration [64] and, since serum creatinine is directly related to muscular mass [65], also higher serum creatinine concentration than young animals, as previously reported in other wild ungulate species $[66,67]$. Higher ALP activities in young animals due to increased bone isoenzyme have been repeatedly reported in wild ungulates $[68,69]$. The higher serum creatinine and total protein concentrations and AST activity observed in the female wild boar as compared to males suggest a higher stress level in females. AST is a nonspecific but sensitive marker of soft tissue damage [69], whereas creatinine is directly related to muscular mass, and therefore it would be expected to be higher in males, but it may also increase due to renal vasoconstriction induced by catecholamines [65,70]. Higher creatinine levels in females, suggesting a higher adrenergic stress response in this gender, have been reported in other wild ungulate species [71]. Increases in AST and creatinine are related to myopathy and renal vasoconstriction, respectively, which are relevant in the pathogenesis of the four capture myopathy syndromes [46,72]. Nevertheless, and since other stress indicators, like body temperature and other serum enzymatic activities, did not indicate this possible higher stress in females, these results should be considered with caution.

The effects of increasing dosages (longer RP and higher initial respiratory rate, and lower serum enzymatic activity and serum lactate, urea, and triglyceride concentrations) suggest that the wild boar receiving a higher dose experienced less stress, although the longer RP could induce a more intense stress which would be undetected, since monitoring took place during HP. A longer RP with increasing doses has been reported both for wild boar and feral pigs [14,41]. The benefits (lower stress) and risks (longer RP) of higher doses should be counterbalanced for each situation when anaesthetizing wild boar in the field.

The effects of good body condition on anaesthetic variables (shorter IP and lower initial respiratory rate and heart rate at 40 minutes), as well as the lower serum glucose concentration, could be explained by a lower plane of body metabolism in wild boar with a higher percentage of body fat [73], as previously reported in feral pigs [41]. Higher serum CK and LDH activities in the wild boar in good body condition could correspond to their greater body size and amount of tissue releasing these enzymes.

Finally, the effects of high temperatures on both anaesthetic variables (longer IP and higher initial body temperature) and serum biochemistry (higher sodium, urea, and creatinine and lower cholesterol and potassium concentrations) indicate dehydration before anaesthesia, which could lead to heat stroke and to an increased risk of developing capture myopathy [46]. Wild boar are especially prone to hyperthermia when exposed to high environmental temperatures [7], and an increase of activity before immobilization can lead to the production of heat muscle and severe elevation of body temperature. Under these circumstances, immediately cooling the animal with cold water, alcohol or ice packs [47] is paramount to enhance welfare and decrease the probability of adverse anaesthetic consequences, thus, increasing survival rate.

\section{Conclusion}

Both, cage and corral traps are efficient methods to capture wild boar. Cage traps are safer, as demonstrated by mortality rates as well as anaesthetic, physiological, and serum biochemical responses. Nevertheless, mortality fell within the lower range of previously reported data and no additional mortality was registered during post-release monitoring. The anaesthetic combination used $(2.9 \mathrm{mg} / \mathrm{kg}$ of $\mathrm{TZ}$ and $0.05 \mathrm{mg} / \mathrm{kg}$ of $\mathrm{M}$ ) is efficient and safe to immobilize physically captured wild boar, and the addition of an $\alpha_{2}$-adrenergic agonist provides suitable analgesia, muscle relaxation and recovery. Trap type, preanaesthetic stress, anaesthetic dose, gender, age, body condition, and environmental temperature affected anaesthetic efficiency and animal welfare. All these factors must be taken into account when anaesthetizing free-ranging wild boar. In conclusion, this anaesthetic protocol is useful for prolonged handling of wild boar and allows sampling and collecting data for ecological and epidemiological studies. 


\section{Abbreviations}

M: Medetomidine; X: Xilacine; TZ: Tiletamine-zolazepam; HPI: Human presence until injection; IP: Induction period; HP: Hypnosis period RP: Recovery period; ALT: Serum alanine aminotransferase; AP: Alkaline phosphatise; AST: Aspartate aminotransferase; CK: Creatine kinase; LDH: Lactate dehydrogenase; GPS: Global position system; GSM: Global system for mobile communications; GLMz: Generalized linear models; SD: Standard deviation.

\section{Competing interests}

The authors declare that they have no competing interests.

\section{Authors' contributions}

$J A B$ and JV designed and carried out the study. JV and JRLO provided guidance on anaesthetic and statistical aspects of the study. JAB, BB and JV were involved in field work and data collection. JAB, JV, JRLO, BB and CG assisted in data interpretation and drafting the manuscript. All authors contributed to the critical revision of the manuscript for important intellectual content and have seen and approved the final draft.

\section{Acknowledgements}

This study was funded by the research projects FAU2008-00004-C03-01 and AGL2010-20730-C02-01 (Spanish Ministry). We thank colleagues from IREC and colleagues from the Cabañeros National Park for their kind help. JA Barasona holds an FPU pre-doctoral scholarship funded by the Spanish Ministry of Education and Science. B Beltrán is financed by PhD studentship BES-2009-017401 of the Spanish Ministry of Economy and Competitiveness. We also thank Ursula Höfle for her valuable comments on the study.

\section{Author details}

${ }^{1}$ Sanidad y Biotecnología (SaBio), Instituto de Investigación en Recursos Cinegéticos (IREC; CSIC - UCLM - JCCM), Ronda de Toledo, Ciudad Real s.n. 13005, Spain. ${ }^{2}$ Servei d'Ecopatologia de Fauna Salvatge (SEFaS), Universitat Autònoma de Barcelona (UAB), Barcelona, Bellaterra E-08193, Spain.

Received: 11 February 2013 Accepted: 14 May 2013

Published: 23 May 2013

\section{References}

1. Broom D, Johnson K: Stress and animal welfare. London: Chapman and Hall; 1993.

2. Dawkins MS: A user's guide to animal welfare science. Trends Ecol Evol 2006, 21:77-82.

3. Powell RA, Proulx G: Trapping and marking terrestrial mammals for research: integrating ethics, performance criteria, techniques, and common sense. ILAR J 2003, 44:259-276.

4. Gordon IJ, Hester AJ, Festa-Bianchet M: Review: the management of wild large herbivores to meet economic, conservation and environmental objectives. J App Ecol 2004, 41:1021-1031.

5. Sàez-Royuela C, Telleria JL: The increased population of wild boar (Sus scrofa) in Europa. Mamm Rev 1986, 16:97-101.

6. Geisser H, Reyer HU: Efficacy of hunting, feeding, and fencing to reduce crop damage by wild boar. J Wildl Manage 2004, 68:939-946.

7. Baber D, Coblentz B: Density, home range, habitat use, and reproduction in feral pigs on Santa Catalina Island. J Mammal 1986, 67:512-552.

8. Naranjo V, Gortázar C, Vicente J, de la Fuente J: Evidence of the role of European wild boar as a reservoir of Mycobacterium tuberculosis complex. Vet Microbiol 2008, 127:1-9.

9. $\quad$ Meng $X$, Lindsay D: Wild boar as sources for infectious diseases in livestock and humans. Phil Trans R Soc B 2009, 364:2697-2707.

10. Jullien JM: Sélectivité de cinq modes de piégeage pour lê Sanglier. In Proceedings of the Symposium on Techniques de capture et de marquage des ongulés sauvages: 20-22 March 1990; Meze-Hérault. Edited by Dubray D. Montpellier: FDC; 1990:95-101.

11. Vassant J, Brandt S: Adaptation du piégeage par enclos-piège de type corral pour la capture de compagnies de sangliers. Gibier Faune Sauvage 1995, 12:51-61.

12. Hebeisen C, Fattebert J, Baubet E, Fischer C: Estimating wild boar (Sus scrofa) abundance and density using capture-resights in Canton of Geneva, Switzerland. Eur J Wildl Res 2008, 54:391-401.
13. Gallagher JF, Lochmiller RL, Grant WE: Immobilization of collared peccaries with ketamine hydrochloride. J Wildl Manage 1985, 49(2):356-357.

14. Fournier P, Fournier-Chambrillon C, Maillard D, Klein F: Zoletil immobilization of wild boar (Sus scrofa L.). J Mt Ecol 1995, 3:134-136.

15. Gabor T, Hellgren E, Silvy N: Immobilization of collared peccaries (Tayassu tajacu) and feral hogs (Sus scrofa) with Telazol and Xylazine. J Wildl Dis 1997, 33(1):161-164.

16. Sutherland-Smith M, Campos JM, Cramer C, Thorsdtadt C, Toone W, Morris PJ: Immobilization of Chacoan peccaries (Catagonus wagneri) using medetomidine, telazol ${ }^{\circledR}$, and ketamine. J Wildl Dis 2004, 40(4):731-736.

17. Fenati M, Monaco A, Guberti V: Efficiency and safety of xylazine and tiletamine/zolazepam to immobilize captured wild boar (Sus scrofa L. 1758): analysis of field results. Eur J Wildl Res 2008, 54(2):269-274.

18. Nielsen $\mathrm{L}$ : Chemical immobilization of free-ranging terrestrial mammals. In Lumb and Jone's veterinary anesthesia. 3rd edition. Edited by Thurmon JC, Tranquilli WJ, Benson GJ. Baltimore, MD: Williams and Wilkins; 1996:736-764.

19. Sweitzer R, Gonzales B, Gardner I, Vuren D, Wauthman J, Boyce W: A modified panel trap and immobilization technique for capturing multiple wild pigs. Wildl Soc Bull 1997, 25(3):699-705.

20. Enqvist K: Medetomidine /Tiletamine-Zolazepam and Medetomidine /Butorphanol/Tiletamine-Zolazepam: a comparison of two anesthetic regimens for surgical implantation of intraperitoneal radiotransmitters in free ranging juvenile European wild boar (Sus scrofa scrofa). In Proceedings of the Annual Conference-American Association of Zoo Veterinarians: 17-21 September 2000; New Orleans, Louisiana. Edited by American Association of Zoo Veterinarians. American Association of Zoo Veterinarians Annual Proceedings; 2000:303-306

21. Burroughs R, Morkel P, Kock MD, Meltzer D, Hofmeyr M: Chemical immobilization - individual species requirements. In Chemical and physical restraint of wild animals. Edited by Kock MD, Meltzer D, Burroughs R. Greyton, South Africa: Veterinary Association Wildlife Group and International Wildlife Veterinary Services; 2006:116-211.

22. Lin HC, Thurmon JC, Benson GJ, Tranquilli WJ: Telazol: a review of its pharmacology and use in veterinary medicine. J Vet Pharmacol Ther 1993, 16(4):383-418

23. Lin HC: Dissociative anesthetics. In Lumb \& Jones'Veterinary Anesthesia. Edited by Thurmon JC, William JT, Benson GJ. Baltimore: Williams \& Wikins; 1996.

24. Tranquilli $W$, Maze $M$ : Clinical pharmacology and use of $a-2$ adrenergic agonist in veterinary anesthesia. Anesth Pharmacol Rev 1993, 1:297-309.

25. Charney DS, Mihic SJ, Harris RA: Hypnotics and sedatives. In Goodman \& Gilman's Pharmacological Basis of Therapeutics. 10th edition. Edited by Hardman JG, Limbird LE. New York: McGraw-Hill; 2001:399.

26. Maze $M$, Tranquilli W: Alpha-2 adrenoceptor agonists: defining the rol in clinical anesthesia. Anethesiology 2001, 74:581-605.

27. Lundy J: Balanced anesthesia. Minn Med 1926, 9:933.

28. Hellgren EC, Lochmiller RL, Amoss MS Jr, Grant WE: Endocrine and metabolic responses of the collared peccary (Tayassu tajacu) to immobilization with ketamine hydrochloride. J Wildl Dis 1985, 21(4):417-425

29. Tast A, Halli O, Peltronieri OA: A pratical method for nonsurgically inserting intra-arterial catheters in European Wild Boar (Sus scrofa). Vet Res Commun 2000, 24(1):25-30.

30. Wolkers J, Wensing T, Groot Bruinderink GW, Schonewille AT: Nutritional status of wild boar (Sus scrofa): II. Body fat reserves in relation to haematology and blood chemistry. Comp Biochem Physiol A Physiol 1993, 105:539-542.

31. Wolkers J, Wensing T, Groot Bruinderink GW, Schonewille JT: Lungworm and stomach worm infection in relation to body fat reserves and blood composition in wild boar (Sus scrofa). Vet Q 1994, 16:193-195.

32. Wolkers J, Wensing T, Groot Bruinderink GW, Schonewille JT: The effect of undernutrition on haematological and serum biochemical variables in wild boar (Sus scrofa). Comp Biochem Physiol A Physiol 1994, 108:431-437.

33. López-Olvera JR, Höfle U, Vicente J, Fernández-de-Mera IG, Gortázar C: Effect of parasitic helminths and ivermectin treatment on clinical parameters in the European wild boar (Sus scrofa). Parasitol Res 2006, 98:582-587.

34. Wolkers J, Wensing T, Groot Bruinderink GW: Sedation of wild boar (Sus scrofa) and red deer (Cervus elaphus) with medetomidine and the influence on some haematological and serum biochemical variables. Vet Q 1994, 16:7-9.

35. Matschke G: Aging European wild hogs by dentition. J WIdl Manage 1967, 31:109-113. 
36. Baubet $E$, Brandt $\mathrm{S}$, Jullien JM, Vassant J: Valeur de l'examen de la denture pour la determination de l'age chez le sanglier (Sus scrofa). Gibier Faune Sauvage 1994, 11:119-132.

37. Carmona JM: Extracción de sangre en el seno oftálmico del cerdo. [http// www.ivis.org/advances/suis/A5508.0711.ES.pdf]

38. Baubet E, Brandt S, Vassant J, Gendner JP, Klein F: Can wild boar be surveyed using GPS? Mem Natl Inst Polar Res, Spec Issue 2004, 58:188-195.

39. Cano-Manuel J, Granados JE, Castillo A, Serrano E, Pérez JM, Soriguer RC, Fandos P, Travesí R: Nuevas tecnologías aplicadas al seguimiento de ungulados silvestres en Sierra Nevada: Collares GPS-GSM. In Biodiversidad y conservación de fauna y flora en ambientes mediterráneos. Edited by Sierra Nevada: Collares GPS-GSM Ntaasduse, Barea JM, Ballesteros E, Luzón JM, Moleón M, Tierno JM. Granada: SGHG; 2007:691-705.

40. Schall R: Estimation in generalized linear models with random effects. Biometrika 1991, 78:719-727.

41. Sweitzer R, Ghneim G, Gardner I, Vuren D, Gonzales B, Boyce W: Immobilization and physiological parameters associated with chemical restraint of wild pigs with Telazol and Xylazine Hydrochloride. J Wildl Dis 1997, 33(2):198-205.

42. Shender LA, Botzler RG, George TL: Analysis of serum and whole blood values in relation to helminth and ectoparasite infections of feral pigs in Texas. J Wildl Dis 2002, 38:385-394.

43. Harapain I, Bedrica L, Hahn V, Sostaric B, Gracner D: Haematological and biochemical values in blood of wild boar (Sus scrofa ferus). Veterinarski arhiv 2003, 73:333-343

44. Vidal D, Naranjo V, Mateo R, Gortazar C, de la Fuente J: Analysis of serum biochemical parameters in relation to Mycobacterium bovis infection of European wild boars (Sus scrofa) in Spain. Eur J Wildl Res 2006, 52:301-304

45. Kahn CM, Line S, Allen DG: The Merck veterinary manual. Whitehouse Station, New Jersey: Merck \& Co; 2005

46. Spraker TR: An overview of the pathophysiology of capture myopathy and related conditions that occur at the time of capture of wild animals. In Chemical Immobilization of North American Wildlife. Edited by Nielsen L, Haigh JC, Fowler ME. Milwaukee, USA: Wisconsin Humane Society; 1982:83-118.

47. Moon P, Smith L: General anesthetic techniques in swine. Vet Clin North Am Food Anim Pract 1996, 12:663-691.

48. Berducou C: Chamois et isards: bilan des captures par filets, pieges et engins drivers realisees en France au cours des trente dernieres annees (1958-1989). In Workshop on techniques de capture et de marquage des ongulés sauvage. Edited by Dubray D. Montpellier: Office National de la Chasse et Ministère Chargé de l'Environnemen; 1993:113-120.

49. López-Olvera JR, Marco I, Montané J, Casas-Díaz E, Mentaberre G, Lavín S: Comparative evaluation of effort, capture and handling effects of drive nets to capture roe deer (Capreolus capreolus), Southern chamois (Rupicapra pyrenaica) and Spanish ibex (Capra pyrenaica). Eur J Wildl Res 2009, 55(3):193-202

50. Cattet MR, Caulkett NA, Polischuk SC, Ramsay MA: Reversible immobilization of free-ranging polar bears with medetomidinezolazepam-tiletamine and atipamezole. J Wildl Dis 1997, 33(3):611-617.

51. Baber DW, Coblentz BE: Immobilization of feral pigs with a combination of ketamine and xylazine. J Wildl Manage 1982, 46(2):557-559.

52. Ajadi AR, Olusa TA, Smith OF, Ajibola ES, Adeleye OE, Adenubi OT, Makinde FA: Tramadol improved the efficacy of ketamine-xylazine anaesthesia in young pigs. Vet Anaesth Analg 2009, 36(6):562-566.

53. Jalanka HH, Roeken BO: The use of medetomidine, medetomidineketamine combinations, and atipamezole in nondomestic mammals: a review. J Zoo Wildl Med 1990, 21(3):259-282.

54. Lee JY, Jee HC, Jeong SM, Park CS, Kim MC: Comparison of anaesthetic and cardiorespiratory effects of xylazine or medetomidine in combination with tiletamine/zolazepam in pigs. Vet Rec 2010, 167(7):245-249.

55. Thurmon J, Benson C, Tranquilli W, Olson W: The anesthetic and analgesic effects of Telazol and xylazine in pigs. evaluating clinical trials. Vet Med 1988, 83:841-845

56. Ko JC, Williams BL, Smith VL, MCGrath CJ, Jacobson JD: Comparison of telazol, telazol-ketamine, telazol-xylazine, and telazol-ketamine-xvlazine as chemical restraint and anesthetic induction combination in swine. Lab Anim Sci 1993, 43(5):476-480.

57. Allen J: Immobilization of giant Chacoan peccaries (Catagonus wagneri) with a tiletamine hydrochloride/ zolazepam hydrochloride combination. J Wildl Dis 1992, 28(3):499-501.
58. Siemon A, Wiesner H, von Hegel G, Hellabrunn MT: The use of tiletamine/ zolazepam/romifidine for distant immobilization of wild boars. Tierarztl Prax 1992, 20:55-58.

59. Boitani L, Mattei L, Nonis D, Corsi F: Spatial and activity patterns of wild boars in Tuscany, Italy. J Mammal 1994, 75(3):600-612.

60. Fowler ME: Restraint and handling of wild and domestic animals. 2nd edition. Ames, USA: lowa State University Press; 1995.

61. Kaneko JJ: Carbohydrate metabolism and its diseases. In Clinical Biochemistry of Domestic Animals. 5th edition. Edited by Kaneko JJ, Harvey JW, Bruss ML. San Diego: Academic Press Inc; 1997:45-81.

62. DiBartola SP, de Morais Autrain H: Hypokalemia and hyperkalemia. In Fluid Therapy in Small Animal Practice. 2nd edition. Edited by DiBartola SP. Philadelphia: Saunders WB Company; 2000:83-107.

63. Hall LW, Clarke KW, Trim CM: Veterinary Anaesthesia. 10th edition. London, United Kingdom: W.B. Saunders; 2001

64. Kaneko JJ: Serum proteins and dysproteinemias. In Clinical Biochemistry of Domestic Animals. 5th edition. Edited by Kaneko JJ, Harvey JW, Bruss ML. San Diego: Academic Press Inc; 1997:117-138.

65. Finco DR: Kidney function. In Clinical Biochemistry of Domestic Animals. 5th edition. Edited by Kaneko JJ, Harvey JW, Bruss ML. San Diego: Academic Press Inc; 1997:485-516.

66. Kock MD, Jessup DA, Clark RK, Franti CE: Effects of capture on biological parameters in free-ranging bighorn sheep (Ovis canadensis): evaluation of dropnet, drive-net, chemical immobilization and the net-gun. J Wild Dis 1987, 23(4):641-651.

67. López-Olvera JR, Marco I, Montané J, Lavín S: Haematological and serum biochemical values of southern chamois (Rupicapra pyrenaica). Vet Rec 2006, 158:479-484.

68. Kock MD, Clark RK, Franti CE, Jessup DA, Wehausen JD: Effects of capture on biological parameters in free-ranging bighorn sheep (Ovis canadiensis): evaluation of normal, stressed and mortality outcomes and documentation of postcapture survival. J Wild Dis 1987, 23(4):652-662.

69. Kramer JW, Hoffmann WE: Clinical enzymology. In Clinical Biochemistry of Domestic Animals. 5th edition. Edited by Kaneko JJ, Harvey JW, Bruss ML. San Diego: Academic Press Inc; 1997:303-325.

70. Harthoorn AM: Physiology of capture myopathy. Quinquennial report. Pretoria: Transvaal Nature Conservation Division; 1976.

71. López-Olvera JR, Marco I, Montané J, Casas-Díaz E, Lavín S: Effects of acepromazine on the stress response in Southern chamois (Rupicapra pyrenaica) captured by means of drive-nets. Can J Vet Research 2007, 71:41-51.

72. Williams ES, Thorne T: Exertional myopathy (capture myopathy). In Noninfectious diseases of wildlife. 2nd edition. Edited by Fairbrother A, Nocke LN, Hoff GL. Ames: lowa State University Press; 1996:181-193.

73. Lumb W, Jones E: Veterinary anesthesia. Pennsylvania: Lea and Febiger; 1996.

\section{doi:10.1186/1746-6148-9-107}

Cite this article as: Barasona et al:: Trap-effectiveness and response to tiletamine-zolazepam and medetomidine anaesthesia in Eurasian wild boar captured with cage and corral traps. BMC Veterinary Research 2013 9:107.

\section{Submit your next manuscript to BioMed Central and take full advantage of:}

- Convenient online submission

- Thorough peer review

- No space constraints or color figure charges

- Immediate publication on acceptance

- Inclusion in PubMed, CAS, Scopus and Google Scholar

- Research which is freely available for redistribution 